\title{
GANGGUAN BUNYI BAHASA KADAZANDUSUN DALAM SEBUTAN ARAB OLEH ETNIK KADAZANDUSUN DI RANAU, SABAH
} Language Interference of Kadazandusun in Arabic Pronounciation by the Native Speakers of Kadazandusun in Ranau, Sabah

\author{
${ }^{1}$ MOHD. TAQWUDIN BIN MOHD. YAZID \\ ${ }^{2}$ VERONICA PETRUS ATIN \\ ${ }^{3}$ SAIDATUL NORNIS HJ. MAHALI \\ Pusat Penataran Ilmu dan Bahasa, Universiti Malaysia Sabah, \\ Jalan UMS, 88400 Kota Kinabalu, Sabah. \\ Imohdtaqwudin@ums.edu.my; ${ }^{2}$ vpetrus@ums.edu.my; ${ }^{3}$ saidatul@ums.edu.my \\ Tarikh Dihantar: 22 Jun 2020 / Tarikh Diterima: 20 September 2020
}

\begin{abstract}
Abstrak Gangguan bahasa ialah produk pemindahan bahasa yang berbentuk negatif daripada bahasa pertama (Kadazandusun) kepada bahasa sasaran (Arab). Berdasarkan perbezaan fonem konsonan yang terdapat dalam sistem bunyi kedua-dua bahasa tersebut, penutur jati Kadazandusun dijangka menghadapi kesukaran ketika menyebut huruf-huruf tertentu. Justeru, kajian ini bertujuan untuk merungkai hakikat gangguan bahasa dari sudut fonetik yang berlaku ketika penutur jati Kadazandusun menyebut huruf tersebut. Oleh itu, objektif pertama kajian ini adalah untuk mengenal pasti huruf bahasa Arab yang sukar untuk disebut berdasarkan gangguan bunyi bahasa Kadazandusun dan sebabnya. Objektif yang kedua pula ialah mengenal pasti huruf bahasa Arab yang mudah disebut oleh etnik Kadazandusun dan sebabnya. Kajian ini berbentuk kajian tindakan yang menggunakan satu set ujian sebutan yang diubah suai berasaskan teori Mahjub untuk mendapatkan skor sebutan sembilan bunyi fonem Arab. Responden kajian seramai 21 orang penutur jati Kadazandusun yang terdiri daripada kalangan remaja, dewasa dan warga tua. Pemilihan responden berasaskan keupayaan membaca al-Quran, penguasaan bahasa ibunda dan kawasan penempatan. Hasil ujian dinilai dengan khidmat nasihat daripada penilai yang pakar dalam bidang ilmu al-Quran dan Qiraat. Dapatan kajian mendapati bahawa huruf [ص], [ ض ], [ b ], [ ] ], [ع] dan [ ح ] adalah huruf yang sukar untuk

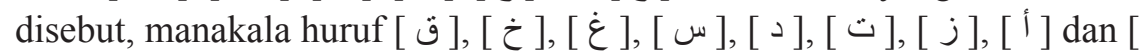
॰] adalah huruf yang mudah untuk disebut. Kajian membuktikan bahawa tahap persamaan dan perbezaan antara sistem fonetik bahasa Kadazandusun
\end{abstract}


dengan bahasa Arab menjadi penentu kepada tahap gangguan bahasa semasa proses pemindahan bahasa. Oleh itu, disarankan agar pembelajaran sebutan huruf Arab dalam kalangan penutur jati Kadazandusun bermula dengan huruf-huruf yang mudah disebut dan diakhiri dengan huruf yang sukar.

Kata kunci: sebutan, fonetik, bahasa Kadazandusun, bahasa Arab, gangguan bahasa, analisis konstruktif.

Abstract Language interference is the negative language transfer product from the first language (Kadazandusun) to the target language (Arabic). Based on consonant phoneme differences in the sound system of both languages, native speakers of Kadazandusun are expected to have difficulty in pronouncing certain Arabic letters. This study therefore was aimed at investigating language interference specifically on the aspect of phonetic that occurred when Kadazandusun native speakers pronounced these particular Arabic letters. The first objective of the study was to identify Arabic letters that posed difficulty in pronunciation due to Kadazandusun language interference and ascertain the reasons for this problem. The second objective was to identify Arabic letters that were easy for Kadazandusun speakers to pronounce and the reasons for this non-difficulty. This action research study utilised an adapted pronunciation test set based on the Mahjub theory in order to obtain scores for nine Arabic pronunciations. The respondents consisted 21 Kadazandusun native speakers comprising teenagers, adults and the elderly. The selection of respondents was based on their ability to read the Quran, mother tongue mastery and their locality. Test results were evaluated with consultation from experts in Quran and Qira'at. Findings revealed [ص], [ ض], [ b],

$[\sqcup],[\varepsilon]$ and $[\tau]$ as letters that the speakers tend to mispronounce

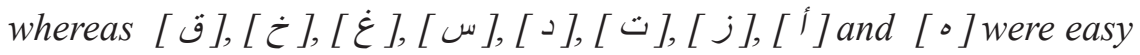
to vocalise. This study has demonstrated that the level of similarities and differences between the phonetic systems of the Kadazandusun and Arabic languages determine the level of interference during language transfer process. Hence it is recommended that the learning of Arabic pronunciation among Kadazandusun native speakers should begin with easier-topronounce letters initially and end with those that are more difficult. 
Keywords: Pronunciation, phonetic, Kadazandusun language, Arabic language, language interference, constructive analysis.

\section{PENDAHULUAN}

Kadazandusun ialah kumpulan etnik terbesar di Sabah dengan bilangan penuturnya mencapai 17.8 peratus berbanding keseluruhan populasi di negeri ini (Adnan \& Hamdan, 2013). Penempatan etnik Kadazandusun yang utama terbahagi kepada dua bahagian, iaitu di pantai timur dan pantai barat Sabah (Ehala, 2010). Daerah Ranau adalah salah satu penempatan etnik Kadazandusun yang terletak di bahagian pedalaman pantai barat. Kelompok ini juga dikenali sebagai dusun tengah (Wurm \& Hattori, 1981).

Bahasa Arab mendapat tempat dalam kalangan masyarakat Kadazandusun di daerah Ranau kesan daripada penyebaran dakwah Islam yang mula bertapak sekitar tahun 1940 (Muhiddin Yusin, 1990:9). Suraya (2013:63) menyatakan Raden Adiniwata atau lebih dikenali sebagai Mandur Syarif merupakan figura penting dan individu yang bertanggungjawab meletakkan batu asas dakwah Islam di daerah Ranau. Hal ini memberikan isyarat jelas bahawa bahasa Arab telah berakar umbi dalam kehidupan beragama masyarakat Kadazandusun. Perkara ini kerana bahasa Arab adalah bahasa al-Quran dan as-Sunah yang menjadi sumber perundangan tertinggi dalam agama Islam. Tambahan itu, bahasa Arab menjadi tunjang kesempurnaan sebahagian besar aktiviti ibadat dan amalan seperti bacaan al-Quran, zikir, wirid, sembahyang, tahlil, tahmid, tasbih, doa, laungan azan, berzanji dan lain-lain lagi. Tegasnya, bahasa Arab dan agama Islam tidak boleh dipisahkan sama sekali.

Pertembungan yang berlaku antara bahasa Kadazandusun sebagai bahasa ibunda kelompok etnik dengan bahasa Arab sebagai bahasa rasmi agama Islam ini seterusnya mengundang gejala gangguan bahasa ketika penutur jati Kadazandusun menyebut huruf-huruf Arab, khususnya dalam aktiviti ibadat atau amalan keagamaan. 
Dalam aspek fonetik, gangguan bahasa berlaku apabila terdapat bunyi-bunyi dalam bahasa Arab yang jauh berbeza dengan bunyi yang terdapat dalam bahasa Kadazandusun, sama ada dari segi mekanisme artikulasi dan bahagian artikulator. Dari sudut yang lain, gangguan bahasa juga boleh berlaku dalam aspek fonologi, morfologi, sintaksis, semantik dan sebagainya (Mohd. Azidan, 2004).

Penentuan bentuk gangguan bahasa dari sudut fonetik boleh dilakukan melalui analisis kontrastif antara sistem bunyi bahasa pertama dengan bahasa kedua. Justeru, kaedah tersebut sering digunakan untuk menentukan aspek-aspek kesukaran dalam pembelajaran sebutan bahasa asing dan membantu memudahkan perancangan kaedah pengajaran yang sesuai (Ashour, 2017; Majid, 2017; Moradi \& Chen, 2018).

\section{Sistem Bunyi Bahasa Arab dan Bahasa Kadazandusun}

Mohd. Taqwudin dan Veronica (2019), dalam satu satu kajian awal tentang perbandingan antara fonem bahasa Arab dengan Kadazandusun mendapati bahawa secara teorinya terdapat persamaan dan perbezaan sistem fonetik yang ketara antara kedua-dua bahasa. Bahasa Arab mempunyai enam fonem vokal, manakala bahasa Kadazandusun hanya empat.

Jadual 1 Perbandingan fonem vokal Arab dan Kadazandusun

\begin{tabular}{|l|l|}
\hline Bahasa Arab & Bahasa Kadazandusun \\
\hline$/ \mathrm{i} /, / \mathrm{i}: /, / \mathrm{u} /, \mathrm{u}: /, / \mathrm{a} /, / \mathrm{a}: /$ & $/ \mathrm{i} /, / \mathrm{u} /, / \mathrm{a} /, / \mathrm{o} /$ \\
\hline
\end{tabular}

Sumber: Mohd. Taqwudin \& Veronica (2019)

Selain itu, bahasa Arab mempunyai 28 fonem konsonan berbanding bahasa Kadazandusun yang hanya memiliki 15 fonem konsonan (Basyīr, 1991; Hanna, 1991:232; Huthaily, 2003:28-29; Rita \& Emilda, 2010; Veronica, 2017:1). 
Jadual 2 Perbandingan fonem konsonan Arab dan Kadazandusun

\begin{tabular}{|c|c|c|c|}
\hline Bil. & Titik Sebutan & Bahasa Arab & $\begin{array}{c}\text { Bahasa } \\
\text { Kadazandusun }\end{array}$ \\
\hline 1 & Dua bibir (bilibials) & ب/b/, م/m/, و/W/, & $/ \mathrm{p} /, / \mathrm{b} /, / \mathrm{m} /, / \mathrm{w} /$ \\
\hline 2 & $\begin{array}{c}\text { Bibir + gigi (labio- } \\
\text { dental) }\end{array}$ & (f/ & - \\
\hline 3 & $\begin{array}{l}\text { Hujung lidah }+ \\
\text { hujung gigi (apico } \\
\text { interdental) }\end{array}$ & 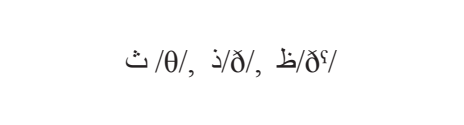 & - \\
\hline 4 & $\begin{array}{c}\text { Hujung lidah }+ \\
\text { pangkal gigi (apico- } \\
\text { dental / denti- } \\
\text { alveolar) }\end{array}$ & ت/t/, , ط/ț & $/ \mathrm{t} /, / \mathrm{d} /$ \\
\hline 5 & $\begin{array}{l}\text { Hujung lidah }+ \text { gusi } \\
\text { (apico-alveolar) }\end{array}$ & 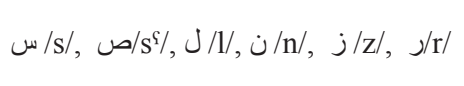 & $/ \mathrm{s} /, / \mathrm{r} /, / 1 /, / \mathrm{n} /$ \\
\hline 6 & $\begin{array}{c}\text { Hujung lidah }+ \\
\text { lelangit keras (apico- } \\
\text { palatal / palato- } \\
\text { alveolar) }\end{array}$ & 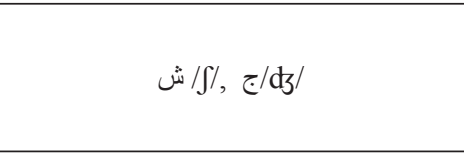 & - \\
\hline 7 & $\begin{array}{l}\text { Tengah lidah }+ \\
\text { lelangit keras } \\
\text { (medio-palatal) }\end{array}$ & 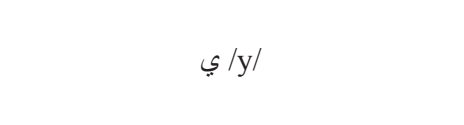 & $/ y /$ \\
\hline 8 & $\begin{array}{l}\text { Pangkal lidah }+ \\
\text { lelangit lembut } \\
\text { (dorso-velar) }\end{array}$ & 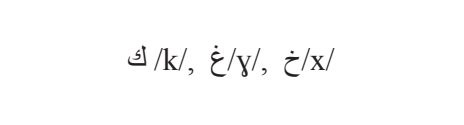 & $/ \mathrm{k} /, / \mathrm{\eta} /, \mathrm{g} /$ \\
\hline 9 & $\begin{array}{l}\text { Pangkal lidah }+ \text { anak } \\
\text { tekak (dorso uvular) }\end{array}$ & 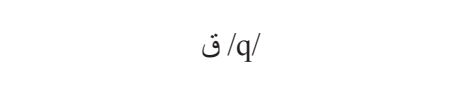 & - \\
\hline 10 & $\begin{array}{l}\text { Pangkal lidah }+ \\
\text { kerongkong }(\text { dorso } \\
\text { pharyngal })\end{array}$ & $\tau / \hbar /, \varepsilon / \mathrm{q} /$ & - \\
\hline 11 & Pita suara (glottal) & $\circ / \mathrm{h} /, \quad, / \mathrm{P} /$ & $/ \mathrm{h} /$ \\
\hline
\end{tabular}

Sumber: Mohd. Taqwudin \& Veronica (2019) berdasarkan titik sebutan.

Menurut Mohd. Taqwudin dan Veronica (2019), penutur jati Kadazandusun dijangka tidak akan menghadapi sebarang kesukaran dalam menyebut fonem vokal Arab disebabkan kemiripan sistem bunyi yang dikongsi bersama. Bagaimanapun, mereka dijangka sukar untuk menyebut beberapa fonem konsonan Arab, khususnya yang tidak wujud dalam sistem bahasa Kadazandusun. Hal ini menunjukkan bahawa keutuhan bahasa 
Kadazandusun sebagai bahasa ibunda memberikan pengaruh gangguan bunyi yang dominan ke atas bahasa Arab (Tarigan, 1988:14).

Fenomena wujudnya sebutan mudah dan sukar timbul kesan daripada proses pemindahan bahasa yang berlaku. Sebutan mudah adalah produk yang terhasil daripada pemindahan positif, sedangkan sebutan sukar adalah produk pemindahan negatif. Pemindahan positif merujuk kepada penggunaan sistem bahasa pertama ketika menggunakan sistem bahasa kedua dan kebetulan wujud persamaan antara kedua-dua sistem tersebut. Sebaliknya, pemindahan negatif merujuk kepada penggunaan sistem bahasa pertama untuk digunakan dalam sistem bahasa kedua sedangkan tidak wujud persamaan antara kedua-dua sistem (Mohd. Azidan, 2004).

Tegasnya, gangguan bahasa adalah produk yang terhasil daripada pemindahan negatif. Justeru, Mohd. Taqwudin dan Veronica (2019) mendakwa bahawa penutur jati Kadazandusun perlu menggandakan usaha ketika mempelajari sebutan fonem konsonan Arab kerana tahap gangguan bahasa yang bakal dihadapi berbeza-beza. Semakin asing sesuatu sistem bunyi, semakin tinggi tahap gangguan bahasa dan semakin sukar untuk dibunyikan (Tarigan, 1988:16).

\section{PERNYATAAN MASALAH}

Gangguan bahasa Kadazandusun terhadap bahasa Arab berlaku semasa proses penyebutan huruf-huruf Arab disebabkan oleh pemindahan dan penggunaan beberapa sistem bunyi bahasa Kadazandusun ke dalam sistem bunyi bahasa Arab, sedangkan sistem tersebut tidak sama dengan sistem bahasa Arab (Tarigan, 1988:16; Mohd Azidan, 2004).

Berdasarkan kajian awal Mohd. Taqwudin dan Veronica (2019) tentang perbandingan fonem bahasa Arab dan Kadazandusun, terdapat sekurang-kurangnya sembilan huruf yang dijangkakan sukar untuk disebut

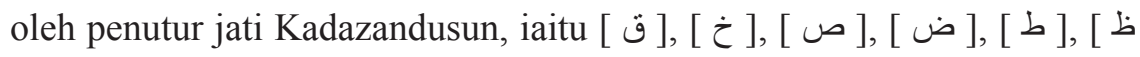
], [ $\varepsilon],[ح]$ dan [ $\dot{\varepsilon}]$. Namun, kajian awal berkenaan berbentuk kajian kepustakaan dan bersifat teorikal semata. Selain itu, Issraq (2017) telah 
menjalankan kajian eksperimen untuk melihat kelemahan sebutan sembilan huruf berkenaan dan seterusnya menggunakan teori Mahjub (1993) untuk menangani masalah sebutan tersebut.

Bagaimanapun, sampel kajian yang dipilih tidak mengkhususkan etnik Kadazandusun. Justeru, kajian ini cuba merungkai persoalan hakikat sebenar gangguan bahasa dari sudut sistem fonetik yang berlaku ketika penutur jati Kadazandusun menyebut huruf bahasa Arab [ ق ], [خ ], [ ص ], [ ض ], [ b ], [ b], [ ع ], [ ح ] dan [غं ] dan sejauh mana gangguan tersebut memberi kesan signifikan kepada perubahan bunyi bahasa.

\section{OBJEKTIF KAJIAN}

Objektif umum penyelidikan ini ialah untuk memahami realiti gangguan bahasa antara Kadazandusun dan bahasa Arab dari perspektif fonetik. Objektif khusus bagi kajian ini adalah seperti yang berikut:

1) Mengenal pasti huruf bahasa Arab yang sukar untuk disebut berdasarkan gangguan bunyi bahasa Kadazandusun dan sebabnya.

2) Mengenal pasti huruf bahasa Arab yang mudah untuk disebut oleh etnik Kadazandusun dan sebabnya.

\section{METODOLOGI KAJIAN}

Reka bentuk kajian ini ialah kajian tinjauan semasa, manakala pelaksanaan kajian ini adalah bersandarkan kaedah kepustakaan dan kaedah lapangan. Menurut Chua (2006), kajian kepustakaan dilakukan bagi mendapatkan informasi lanjut berkenaan subjek kajian dari aspek tajuk, permasalahan, objektif, soalan kajian, tinjauan literatur dan perbincangan. Kajian lapangan pula dilaksanakan untuk memperoleh maklumat primer secara objektif dan terperinci tentang realiti gangguan bunyi bahasa Kadazandusun terhadap sebutan Arab oleh etnik Kadazandusun, serta faktor yang menyebabkan gangguan tersebut berlaku. Semasa kajian lapangan, kaedah ujian sebutan dan rakaman suara responden telah dilakukan. Samarin (1993), berpendapat bahawa sumber autentik dan realistik berkaitan bahasa hanya dapat diperoleh melalui kajian lapangan. 
Semasa membuat kajian lapangan kajian ini menggunakan satu set ujian sebutan yang dibina dan dimodifikasi berasaskan ujian sebutan model Mahjub (1993), iaitu model yang digunakan dalam pembelajaran fonetik moden untuk memperbaiki kesukaran sebutan huruf Arab dalam kalangan penutur bukan Arab. Ujian ini melibatkan sembilan huruf, iaitu [ ق ], [خ ], [ ص], [ض], [ b], [ ], [ع], [ح] dan [غं ] yang setiap satunya disebut dalam 12 bentuk perkataan yang berbeza, baris yang berbeza (baris atas, depan, bawah dan mati), dan kedudukan dalam perkataan yang berbeza (awal, tengah dan akhir perkataan). Jumlah keseluruhan perkataan yang perlu disebut oleh setiap responden adalah sebanyak 108 perkataan. Ujian ini telah diadakan di pelbagai ruangan khas tertutup dan responden dipanggil seorang demi seorang untuk menjalankan ujian sebutan ini. Sebutan responden akan direkodkan menggunakan alat perakam suara digital SONY ICD-UX560F.

\section{Sampel Kajian}

Bagi mendapatkan gambaran yang lebih tepat tentang realiti gangguan bahasa yang berlaku dalam populasi kajian, maka kajian ini meletakkan beberapa kriteria utama dalam pemilihan sampel kajian. Kriteria yang pertama, responden mestilah anak jati Kadazandusun yang mampu membaca tulisan Arab atau al-Quran. Selain itu, responden haruslah terdiri daripada pelbagai lapisan umur bermula daripada golongan remaja, dewasa dan tua. Menurut Noor Aina Dani et al. (2019), kriteria yang terakhir adalah responden sebaiknya dalam kalangan mereka yang pernah mendapat pendidikan bahasa Kadazandusun sama ada secara formal atau tidak formal sejak kecil dan berasal daripada kawasan pedalaman yang kurang berhubung dengan penutur bahasa lain berbanding anak jati yang tinggal di bandar.

Berdasarkan kriteria tersebut seramai 21 orang responden yang terdiri daripada 14 perempuan dan tujuh lelaki, berumur di antara 15 tahun hingga 82 tahun (remaja sembilan orang, dewasa 11 orang dan warga tua seorang) dan berasal dari enam buah kampung (Kampung Desa Aman, Kampung Cinta Mata, Kampung Kundasang, Kampung Waang, Kampung Sinisian dan Kampung Lembah Permai) di sekitar daerah Ranau telah dipilih menggunakan persampelan bertujuan. Responden telah dihubungi melalui telefon untuk mendapatkan persetujuan dan janji temu. Proses mendapatkan data kajian telah dijalankan pada 22 Julai sehingga 14 Ogos 2019. 


\section{Analisis Data}

Analisis data melibatkan kaedah kuantitatif dan data dianalisis dengan menggunakan analisis deskriptif. Data yang dianalisis secara kuantitatif adalah skor sebutan bunyi Arab yang menggunakan instrumen borang penilaian bagi memperoleh kekerapan dan peratusan skor sebutan huruf. Untuk menilai sebutan responden ini, kajian ini menggunakan khidmat nasihat pakar yang berpengalaman dalam ilmu al-Quran dan Qiraat. Penilai akan menandakan tahap ketepatan sebutan Arab, tahap persamaan dengan huruf Arab lain dan tahap gangguan bunyi Kadazandusun dalam satu set jadual penilaian. Berikut adalah nilai skor skala Likert 0 hingga 5 yang digunakan penilai dalam menilai sebutan responden.

Jadual 3 Skor penilaian rakaman suara

\begin{tabular}{|c|c|}
\hline Tahap Ketepatan, Persamaan dan Gangguan & Nilai Skor \\
\hline Sangat Tinggi & 5 \\
\hline Tinggi & 4 \\
\hline Sederhana & 3 \\
\hline Rendah & 2 \\
\hline Sangat Rendah & 1 \\
\hline Langsung tidak tepat atau tiada persamaan/gangguan & 0 \\
\hline
\end{tabular}

\section{DAPATAN KAJIAN DAN PERBINCANGAN}

Dapatan kajian telah berjaya menjawab kedua-dua persoalan kajian yang hendak dikaji. Ketika menghuraikan hasil kajian pengkaji menggunakan istilah huruf ketika merujuk konsonan Arab dan menggunakan istilah konsonan ketika merujuk konsonan bahasa Kadazandusun atau bahasa Melayu. Hal ini bagi memudahkan kefahaman.

\section{Skor Ketepatan Sebutan Huruf}

Hasil kajian mendapati bahawa terdapat gangguan bahasa yang jelas apabila penutur Kadazandusun mengalami kesukaran dalam menyebut huruf [ ص

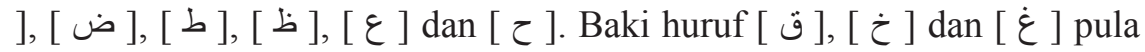


dapat disebut dengan mudah tanpa sebarang gangguan bahasa yang jelas. Hal ini bertentangan dengan kenyataan Mohd. Taqwudin dan Veronica (2019) dan Mahjub (1993) bahawa selain penutur Arab, penutur bahasa lain seperti Kadazandusun sukar untuk menyebut semua huruf tersebut. Jadual berikut menunjukkan analisis skor ketepatan sebutan bagi semua sembilan huruf tersebut.

1. Huruf [ ق ق]

\begin{tabular}{|c|c|c|c|c|c|c|c|}
\hline $\begin{array}{c}\text { Tahap } \\
\text { Ketepatan }\end{array}$ & $\begin{array}{c}\text { Langsung } \\
\text { Tidak Tepat }\end{array}$ & $\begin{array}{l}\text { Sangat } \\
\text { Rendah }\end{array}$ & Rendah & Sederhana & $\begin{array}{c}\text { Tingg } \\
i\end{array}$ & $\begin{array}{l}\text { Sangat } \\
\text { Tinggi }\end{array}$ & Tafsiran \\
\hline Bil. Responden & 2 & 0 & 1 & 1 & 10 & 7 & Huruf [ ق ] \\
\hline Peratusan (\%) & 9.5 & 0 & 4.8 & 4.8 & 47.6 & 33 & mudah disebut \\
\hline \multicolumn{8}{|l|}{ 2. Huruf $[\dot{\tau}]$} \\
\hline Tahap & Langsung & Sangat & Rendah & Sederhana & Tingg & \multirow{4}{*}{$\begin{array}{c}\text { Sangat } \\
\text { Tinggi } \\
8 \\
38.1\end{array}$} & Tafsiran \\
\hline Ketepatan & Tidak Tepat & Rendah & & & $\mathrm{i}$ & & \\
\hline Bil. Responden & 1 & 2 & 4 & 0 & 5 & & Huruf [ $\dot{z}]$ \\
\hline Peratusan (\%) & 4.8 & 9.5 & 19 & 0 & 28.6 & & mudah disebut \\
\hline \multicolumn{8}{|l|}{ 3. Huruf [ص] ] } \\
\hline Tahap & Langsung & Sangat & Rendah & Sederhana & Tingg & \multirow{4}{*}{$\begin{array}{c}\text { Sangat } \\
\text { Tinggi } \\
1 \\
4.8\end{array}$} & Tafsiran \\
\hline Ketepatan & Tidak Tepat & Rendah & & & $\mathrm{i}$ & & \\
\hline Bil. Responden & 1 & 10 & 4 & 3 & 2 & & Huruf [ص] ] \\
\hline Peratusan (\%) & 4.8 & 47.6 & 19 & 14.3 & 9.5 & & sukar disebut \\
\hline \multicolumn{8}{|l|}{ 4. Huruf [ض ] } \\
\hline Tahap & Langsung & Sangat & Rendah & Sederhana & Tingg & \multirow{4}{*}{$\begin{array}{c}\text { Sangat } \\
\text { Tinggi } \\
3 \\
14.3\end{array}$} & Tafsiran \\
\hline Ketepatan & Tidak Tepat & Rendah & & & $\mathrm{i}$ & & \\
\hline Bil. Responden & 1 & 8 & 4 & 3 & 2 & & Huruf [ ض ] \\
\hline Peratusan (\%) & 4.8 & 38.1 & 19 & 14.3 & 9.5 & & sukar disebut \\
\hline \multicolumn{8}{|l|}{ 5. Huruf [ b] } \\
\hline Tahap & Langsung & Sangat & Rendah & Sederhana & Tingg & \multirow{4}{*}{$\begin{array}{c}\text { Sangat } \\
\text { Tinggi } \\
4 \\
19\end{array}$} & Tafsiran \\
\hline Ketepatan & Tidak Tepat & Rendah & & & $\mathrm{i}$ & & \\
\hline Bil. Responden & 2 & 8 & 5 & 2 & 0 & & Huruf [b] \\
\hline Peratusan (\%) & 9.5 & 38.1 & 23.8 & 9.5 & 0 & & sukar disebut \\
\hline \multicolumn{8}{|l|}{ 6. Huruf [ b] } \\
\hline Tahap & Langsung & Sangat & Rendah & Sederhana & Tingg & \multirow{4}{*}{$\begin{array}{c}\text { Sangat } \\
\text { Tinggi } \\
1 \\
4.8\end{array}$} & Tafsiran \\
\hline Ketepatan & Tidak Tepat & Rendah & & & $\mathrm{i}$ & & \\
\hline Bil. Responden & 3 & 15 & 1 & 1 & 0 & & Huruf [ b] \\
\hline Peratusan (\%) & 14.3 & 71.4 & 4.8 & 4.8 & 0 & & sukar disebut \\
\hline \multicolumn{8}{|l|}{ 7. Huruf $[\varepsilon]$} \\
\hline Tahap & Langsung & Sangat & Rendah & Sederhana & Tingg & \multirow{4}{*}{$\begin{array}{c}\text { Sangat } \\
\text { Tinggi } \\
1 \\
4.8\end{array}$} & Tafsiran \\
\hline Ketepatan & Tidak Tepat & Rendah & & & $\mathrm{i}$ & & \\
\hline Bil. Responden & 4 & 4 & 3 & 4 & 5 & & Huruf $[\varepsilon]$ \\
\hline Peratusan (\%) & 19 & 19 & 14.3 & 19 & 23.8 & & sukar disebut \\
\hline
\end{tabular}




\begin{tabular}{|c|c|c|c|c|c|c|c|}
\hline Tahap & Langsung & Sangat & Rendah & Sederhana & Tingg & Sangat & Tafsiran \\
\hline Ketepatan & Tidak Tepat & Rendah & & & $\mathrm{i}$ & Tinggi & \\
\hline Bil. Responden & 13 & 5 & 0 & 1 & 1 & 1 & Huruf [ $[$ ] \\
\hline Peratusan (\%) & 61.9 & 23.8 & 0 & 4.8 & 4.8 & 4.8 & sukar disebut \\
\hline \multicolumn{8}{|l|}{ 9. Huruf $[\dot{\varepsilon}]$} \\
\hline Tahap & Langsung & Sangat & Rendah & Sederhana & Tingg & Sangat & Tafsiran \\
\hline Ketepatan & Tidak Tepat & Rendah & & & $\mathrm{i}$ & Tinggi & \\
\hline Bil. Responden & 2 & 1 & 3 & 4 & 9 & 2 & Huruf [غं ] \\
\hline Peratusan (\%) & 9.5 & 4.8 & 14.3 & 19 & 42.9 & 9.5 & mudah disebut \\
\hline
\end{tabular}

Ketika responden menyebut huruf [ $],[\dot{\tau}]$ dan [ $\dot{\varepsilon}$ ] berlaku pemindahan bahasa yang positif. Hal ini terjadi disebabkan terdapat bunyi Kadazandusun yang hampir sama dengan bunyi tiga huruf Arab tersebut sama ada dari segi daerah sebutan atau cara sebutan.

Dalam sistem bunyi bahasa Arab, huruf [ ق ] ialah bunyi plosif uvular tidak bersuara yang terhasil apabila belakang lidah dirapatkan pada lelangit lembut, dengan cara sebahagian besar pangkal lidah menaik ke atas, untuk membuat sekatan penuh aliran udara. Pita suara berada dalam keadaan terbuka, manakala lelangit lembut dan anak tekak dinaikkan dan dirapatkan pada dinding tekak untuk menghalang udara keluar melalui rongga hidung. Udara dari paru-paru keluar ke rongga mulut tanpa menggetarkan pita suara sebelum tersekat sepenuhnya pada lelangit lembut. Seterusnya, udara dilepaskan dengan serta-merta bagi menghasilkan letupan lelangit lembut tidak bersuara (Basyīr, 1991; Huthaily, 2003).

Seterusnya, huruf $[\dot{\varepsilon}$ ] ialah bunyi frikatif velar bersuara, manakala $[\dot{\tau}$ ] ialah bunyi frikatif velar tidak bersuara. Kedua-dua huruf ini terhasil apabila pangkal lidah dirapatkan pada lelangit lembut, dengan cara sebahagian besar pangkal lidah menaik ke atas, untuk membuat sempitan aliran udara. Jika dilihat secara lebih teliti, ketika pembentukan bunyi huruf [ $\dot{\tau}$ ] pita suara berada dalam keadaan terbuka, seterusnya lelangit lembut dan anak tekak dinaikkan dan dirapatkan pada dinding tekak untuk menghalang udara keluar melalui rongga hidung. Udara dari paru-paru keluar secara menggeser melalui sempitan pada lelangit keras tanpa menggetarkan pita suara bagi menghasilkan bunyi geseran lelangit keras tidak bersuara. Ketika pembentukan bunyi huruf [ $\dot{\varepsilon}$ ] pula, pita suara berada dalam keadaan tertutup, seterusnya lelangit lembut dan anak tekak dinaikkan dan dirapatkan 
pada dinding tekak untuk menghalang udara keluar melalui rongga hidung. Udara dari paru-paru keluar secara menggeser melalui sempitan pada lelangit lembut dengan menggetarkan pita suara bagi menghasilkan bunyi geseran lelangit keras bersuara.

Dari sudut sistem bunyi bahasa Kadazandusun pula, kewujudan konsonan [ $\mathrm{k}$ ] dan vokal [ o ] dalam sistemnya dilihat sebagai dua elemen utama yang memberi pengaruh signifikan dalam memudahkan sistem bunyi Kadazandusun menyebut bunyi huruf Arab [ $]$ ], [ $\dot{c}]$ dan [غ ].

Konsonan [ k ] Kadazandusun ialah bunyi plosif velar tidak bersuara. Berbeza dengan titik sebutan huruf [ $]$ ] pada anak tekak atau uvular, bunyi konsosnan [ $\mathrm{k}$ ] terhasil ketika belakang lidah dirapatkan pada lelangit lembut, dengan cara sebahagian pangkal lidah menurun ke bawah, untuk membuat sekatan penuh aliran udara (Abdullah Hassan, 1980:61; Mohd. Azidan, 2004). Tambahan itu, disebabkan kedudukannya yang sama dengan titik sebutan huruf $[\dot{\tau}]$ dan [ $\dot{\varepsilon}]$ pada lelangit lembut dan sangat hampir dengan titik bunyi huruf Arab [ق ] pada anak tekak, maka ia secara tidak langsung memberi kelebihan kepada penutur jati Kadazandusun untuk membunyikan dengan mudah huruf-huruf berkenaan.

Dari sudut vokal [ o ] Kadazandusun pula, bunyi vokal ini adalah bersuara seperti semua bunyi vokal lain dan penghasilan bunyinya hanya melibatkan udara agresif sahaja, iaitu udara yang dihembus keluar semasa menghasilkan bunyi ini. Selain itu, bunyi tersebut juga dihasilkan tanpa sekatan dan penyempitan yang berlaku antara titik artikulasi dengan artikulator. Ciri tersebut merupakan pembeza utama antara vokal dengan konsonan. Ketika menyebut vokal [o] kedudukan lidah dengan bumbung mulut adalah pada posisi separuh sempit dan separuh luas, manakala bibir akan menjadi bundar (Nor Hasmah, 2000:38-39).

Perlu dijelaskan di sini bahawa bunyi konsonan [ $\mathrm{k}$ ] dan vokal [ o ] Kadazandusun, sedikit berbeza dengan konsonan [ $\mathrm{k}$ ] dan vokal [ o ] bahasa Melayu dari sudut posisi artikulasi atau darjah analisasi. Namun, mekanisme penghasilan bunyi tetap sama. Sebagai contoh, perbezaan bunyi tersebut dapat dikesan dengan jelas ketika menyebut perkataan bahasa 
Kadazandusun /gakod/ - "kaki” dan /kokot/ - "menggigit" dan perkataan bahasa Melayu /komplot/ dan /kolam/.

Perbezaan ketara antara konsonan [ k ] bahasa Kadazandusun berbanding bahasa Melayu ialah titik artikulasi konsonan Kadazandusun lebih ke belakang lelangit lembut dan sangat mendekati bunyi konsonan [ q ] bahasa Melayu atau huruf bahasa Arab [ ق ], membuatkan artikulator pangkal lidah perlu meletakkan tekanan yang lebih tinggi ketika membunyikan konsonan [ k ] Kadazandusun berbanding bahasa Melayu. Kesannya bunyi konsonan [ $\mathrm{k}$ ] lebih tebal dan keras berbanding konsonan bahasa Melayu, namun tidak sampai ke tahap bunyi konsonan [ q ] bahasa Melayu atau huruf bahasa Arab [ ق ]

Berbeza dengan bahasa Melayu, konsonan [ o ] Kadazandusun sebenarnya lebih sengau. Kesan sengau atau analisasi tersebut muncul apabila velum diturunkan bagi membolehkan udara keluar melalui rongga hidung. Di samping itu, udara juga bebas keluar melalui rongga mulut tanpa sekatan (Nor Hasmah, 2000:40-41). Peranan vokal [ o ] dalam sistem bunyi bahasa Kadazandusun adalah sangat unik kerana vokal tersebut antara lain menjadikan ciri bunyi analisasi vokal [ o ] sebagai identiti bahasa yang cukup dominan dalam sistem bunyinya. Rajah 1 menunjukkan kedudukan vokal [ o ] dalam sistem bunyi bahasa Kadazandusun.

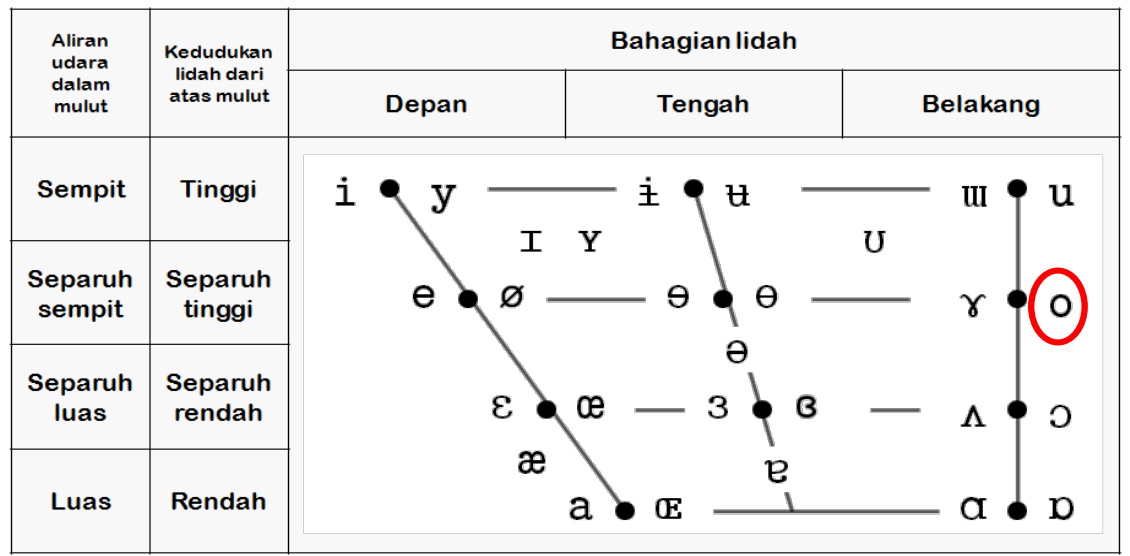

Rajah 1 Kedudukan vokal [ o ] Kadazandusun Sumber: Rita \& Emilda (2010) dan Veronica (2017). 
Berdasarkan keterangan titik artikulasi dan sistem artikulator konsonan [ $\mathrm{k}$ ] dan vokal [ o ] bahasa Kadazandusun sebelum ini, kombinasi antara kedua-dua konsonan dan vokal tersebut dalam membentuk binaan suku kata atau fonem /ko/ akan menghasilkan satu ciri bunyi tebal yang eksklusif bagi bahasa ini. Bunyi tebal yang wujud dalam sistem bunyi Kadazandusun tersebut sangat mirip dengan gejala bunyi tebal yang terdapat pada bunyi huruf Arab [ $],[\dot{\tau}]$ dan [ $\dot{\varepsilon}$ ] yang lebih dikenali sebagai tafkhìm. Namun begitu, bunyi tebal tafkhìm dalam bahasa Arab terbentuk disebabkan sifat 'isti' $l \bar{a}$ ' (keadaan sebahagian besar pangkal atau belakang lidah terangkat ke lelangit lembut) yang dimiliki oleh tiga huruf berkenaan (Al-Juraysī, 1999: 75).

Kesimpulannya, konsonan [ $\mathrm{k}$ ] dan vokal [ o ] berfungsi sebagai titik penyatu antara sistem bunyi bahasa Kadazandusun dan bahasa Arab dalam konteks penyebutan bunyi huruf [ $],[\dot{\tau}]$ dan [غ ]. Justeru, penutur jati Kadazandusun mampu menyebut huruf Arab [ $[$ ], [ $\dot{\tau}$ ] dan [غ ] dengan mudah. Namun begitu, hasil kajian menunjukkan tetap terdapat sebahagian kecil responden yang menyebut huruf [ $[\mathrm{G}$ sebagai [ [ ] atau [ $\mathrm{k}$ ] seramai (9.6 peratus) dan huruf [ $\dot{\tau}$ ] sebagai [ ق $]$ seramai (9.6 peratus) atau [ h ] seramai (4.8 peratus).

Berbeza dengan huruf Arab [ $],[\dot{\tau}]$ dan [ $\dot{\varepsilon}]$ sebelum ini, secara umumnya penutur Kadazandusun didapati menghadapi masalah menyebut bunyi huruf Arab [ ص ] sebanyak (71.4 peratus), [ ض ] sebanyak (61.9 peratus), [ b ] sebanyak (71.4 peratus) dan [ b ] sebanyak (90.5 peratus). Mereka sukar membunyikan huruf-huruf tersebut secara lebih tebal ( 'it disebabkan tidak mempunyai pengalaman menghadapi ciri sebutan hurufhuruf tersebut dalam bahasa ibunda. Ketika menyebut huruf-huruf 'iṭbāq tersebut, selain sebahagian besar pangkal lidah terangkat ke lelangit lembut ( 'isti 'la' '), daun lidah juga sedikit terangkat ke lelangit keras sehingga pipi mengembung dan berbunyi seakan 'o' tanpa membundarkan bibir. Hal inilah yang menjadi kesukaran buat penutur Kadazandusun sehingga akhirnya tanpa sengaja mereka membunyikan huruf lain yang bunyinya hampir sama dan lebih mudah untuk disebut menurut sistem bunyi bahasa mereka. 
Selain itu, Jadual 4 turut menunjukkan bahawa 52.3 peratus penutur jati Kadazandusun sukar menyebut huruf [ $\varepsilon$ ] dan 85.7 peratus sukar menyebut huruf $[\tau]$ disebabkan bunyi seumpama itu tidak wujud dalam sistem bahasa mereka. Ironinya, penutur jati Kadazandusun cenderung membunyikan [ ? ] ketika menyebut huruf [ $\varepsilon$ ] dan membunyikan [ h ] ketika menyebut huruf $[\tau]$.

Keterangan lanjut berkenaan kelemahan yang dihadapi penutur Kadazandusun dalam sebutan bunyi huruf [ص], [ض], [ [ ] ] [ ], [ع] dan [ح ] akan diberikan ketika membahas hasil kajian bagi skor tahap perubahan bunyi sebutan satu huruf Arab menjadi bunyi huruf lain.

\section{Skor Tahap Perubahan Bunyi Sebutan Satu Huruf Arab kepada Huruf Lain}

Hasil kajian mendapati bahawa terdapat gangguan bahasa yang menyukarkan sebutan penutur Kadazandusun sehingga membunyikan huruf Arab yang berbeza tanpa disengajakan ketika menyebut huruf-huruf [ص], [ص [ [ ] [ ] ], [ $]$ ], [ ع ] dan [ ح ]. Hal ini antara lain menunjukkan bunyi huruf Arab yang menggantikan bunyi huruf sukar tersebut boleh dianggap sebagai huruf yang mudah untuk disebut, sekali gus mengisyaratkan berlaku pemindahan bahasa yang positif. Huruf-huruf yang mudah disebut termasuklah huruf

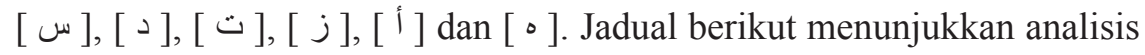
skor tahap persamaan bunyi sebutan huruf Arab yang sukar dengan bunyi huruf Arab yang lain. 
Jadual 5 Skor perubahan bunyi huruf [ ص ] menjadi huruf [ س ] 1. Huruf [ ص] disebut sebagai huruf [ w].

\begin{tabular}{|c|c|c|c|c|c|c|c|}
\hline Tahap Persamaan & $\begin{array}{c}\text { Langsung Tiada } \\
\text { Persamaan }\end{array}$ & $\begin{array}{l}\text { Sangat } \\
\text { Rendah }\end{array}$ & Rendah & Sederhana & Tinggi & $\begin{array}{l}\text { Sangat } \\
\text { Tinggi }\end{array}$ & Tafsiran \\
\hline \multirow{2}{*}{$\begin{array}{l}\text { Bil. Responden } \\
\text { Peratusan (\%) }\end{array}$} & 0 & 2 & 3 & 5 & 5 & \multirow{2}{*}{$\begin{array}{c}6 \\
28.6\end{array}$} & \multirow{2}{*}{$\begin{array}{c}\text { Huruf [ w] } \\
\text { mudah disebut }\end{array}$} \\
\hline & 0 & 9.5 & 14.3 & 23.8 & 23.8 & & \\
\hline \multicolumn{7}{|c|}{ 1.1.1 Ketika berbaris atas (fathat) } & \\
\hline Bil. Responden & 9 & 2 & 9 & 1 & 0 & 0 & \\
\hline Peratusan $(\%)$ & 42.9 & 9.5 & 42.9 & 4.8 & 0 & 0 & \\
\hline 1.1.2 Ketika berba & s depan (dammat) & & & & & & \\
\hline Bil. Responden & 1 & 1 & 4 & 1 & 2 & 12 & \\
\hline Peratusan (\%) & 4.8 & 4.8 & 19 & 4.8 & 9.5 & 57.1 & \\
\hline 1.1.3 Ketika berba & s bawah (kasrat) & & & & & & \\
\hline Bil. Responden & 2 & 1 & 2 & 1 & 1 & 14 & \\
\hline Peratusan $(\%)$ & 9.5 & 4.8 & 9.5 & 4.8 & 4.8 & 66.7 & \\
\hline 1.1.4 Ketika berba & s mati (sukun) & & & & & & \\
\hline Bil. Responden & 4 & 0 & 4 & 1 & 1 & 11 & \\
\hline Peratusan $(\%)$ & 19 & 0 & 19 & 4.8 & 4.8 & 52.4 & \\
\hline
\end{tabular}

\section{Jadual 6 Skor perubahan bunyi huruf [ ض ] menjadi huruf [ د ]} 2. Huruf [ ض ] disebut sebagai huruf [ 2 ].

\begin{tabular}{|c|c|c|c|c|c|c|c|}
\hline Tahap Persamaan & $\begin{array}{c}\text { Langsung Tiada } \\
\text { Persamaan }\end{array}$ & $\begin{array}{l}\text { Sangat } \\
\text { Rendah }\end{array}$ & Rendah & Sederhana & Tinggi & $\begin{array}{l}\text { Sangat } \\
\text { Tinggi }\end{array}$ & Tafsiran \\
\hline Bil. Responden & 1 & 2 & 3 & 3 & 4 & 8 & Huruf [2] \\
\hline Peratusan (\%) & 4.8 & 9.5 & 14.3 & 14.3 & 19 & 38.1 & mudah disebut \\
\hline \multicolumn{7}{|c|}{ 2.1.1 Ketika berbaris atas (fathat) } & \\
\hline Bil. Responden & 6 & 5 & 9 & 0 & 0 & 1 & \\
\hline Peratusan (\%) & 28.6 & 23.8 & 42.9 & 0 & 0 & 4.8 & \\
\hline \multicolumn{7}{|c|}{ 2.1.2 Ketika berbaris depan (dammat) } & \\
\hline Bil. Responden & 5 & 2 & 1 & 1 & 1 & 11 & \\
\hline Peratusan $(\%)$ & 23.8 & 9.5 & 4.8 & 4.8 & 4.8 & 52.4 & \\
\hline \multicolumn{7}{|c|}{ 2.1.3 Ketika berbaris bawah (kasrat) } & \\
\hline Bil. Responden & 3 & 3 & 1 & 2 & 0 & 12 & \\
\hline Peratusan $(\%)$ & 14.3 & 14.3 & 4.8 & 9.5 & 0 & 57.1 & \\
\hline \multicolumn{7}{|c|}{ 2.1.4 Ketika berbaris mati (sukun) } & \\
\hline Bil. Responden & 1 & 1 & 2 & 1 & 0 & 16 & \\
\hline Peratusan (\%) & 4.8 & 4.8 & 9.5 & 4.8 & 0 & 76.2 & \\
\hline
\end{tabular}


Jadual 7 Skor perubahan bunyi huruf $[\mathrm{b}]$ menjadi huruf $[\bullet]$ 3. Huruf $[\mathrm{b}]$ disebut sebagai huruf $[ت]$.

\begin{tabular}{|c|c|c|c|c|c|c|c|}
\hline Tahap Persamaan & $\begin{array}{l}\text { Langsung Tiada } \\
\text { Persamaan }\end{array}$ & $\begin{array}{l}\text { Sangat } \\
\text { Rendah }\end{array}$ & Rendah & Sederhana & Tinggi & $\begin{array}{l}\text { Sangat } \\
\text { Tinggi }\end{array}$ & Tafsiran \\
\hline Bil. Responden & 1 & 3 & 2 & 4 & 5 & 6 & Huruf [ ت] \\
\hline Peratusan (\%) & 4.8 & 14.3 & 9.5 & 19 & 23.8 & 28.6 & mudah disebut \\
\hline \multicolumn{7}{|c|}{ 3.1.1 Ketika berbaris atas (fathat } & \\
\hline Bil. Responden & 8 & 4 & 7 & 0 & 0 & 2 & \\
\hline Peratusan (\%) & 38.1 & 19 & 33.3 & 0 & 0 & 9.5 & \\
\hline \multicolumn{7}{|c|}{ 3.1.2 Ketika berbaris depan (dammat) } & \\
\hline Bil. Responden & 1 & 4 & 3 & 1 & 1 & 11 & \\
\hline Peratusan $(\%)$ & 4.8 & 19 & 14.3 & 4.8 & 4.8 & 52.4 & \\
\hline \multicolumn{7}{|c|}{ 3.1.3 Ketika berbaris bawah (kasrat) } & \\
\hline Bil. Responden & 2 & 3 & 0 & 0 & 3 & 13 & \\
\hline Peratusan (\%) & 9.5 & 14.3 & 0 & 0 & 14.3 & 61.9 & \\
\hline \multicolumn{7}{|c|}{ 3.1.4 Ketika berbaris mati (sukun) } & \\
\hline Bil. Responden & 3 & 2 & 3 & 0 & 2 & 11 & \\
\hline Peratusan (\%) & 14.3 & 9.5 & 14.3 & 0 & 9.5 & 52.4 & \\
\hline
\end{tabular}

Jadual 8 Skor perubahan bunyi huruf [ $[$ ] menjadi huruf [ j] 4. Huruf [ $[$ ] disebut sebagai huruf $[j]$.

\begin{tabular}{|c|c|c|c|c|c|c|c|}
\hline Tahap Persamaan & $\begin{array}{c}\text { Langsung Tiada } \\
\text { Persamaan }\end{array}$ & $\begin{array}{l}\text { Sangat } \\
\text { Rendah }\end{array}$ & Rendah & Sederhana & Tinggi & $\begin{array}{l}\text { Sangat } \\
\text { Tinggi }\end{array}$ & Tafsiran \\
\hline Bil. Responden & 0 & 1 & 1 & 3 & 3 & 13 & Huruf [ j] \\
\hline Peratusan (\%) & 0 & 4.8 & 4.8 & 14.3 & 14.3 & 61.9 & mudah disebut \\
\hline \multicolumn{7}{|c|}{ 4.1.1 Ketika berbaris atas (fathat $)$} & \\
\hline Bil. Responden & 0 & 4 & 14 & 1 & 1 & 1 & \\
\hline Peratusan (\%) & 0 & 19 & 66.7 & 4.8 & 4.8 & 4.8 & \\
\hline \multicolumn{7}{|c|}{ 4.1.2 Ketika berbaris depan (dammat) } & \\
\hline Bil. Responden & 2 & 2 & 0 & 1 & 0 & 16 & \\
\hline Peratusan (\%) & 9.5 & 9.5 & 0 & 4.8 & 0 & 76.2 & \\
\hline \multicolumn{7}{|c|}{ 4.1.3 Ketika berbaris bawah (kasrat) } & \\
\hline Bil. Responden & 2 & 1 & 2 & 0 & 2 & 14 & \\
\hline Peratusan $(\%)$ & 9.5 & 4.8 & 9.5 & 0 & 9.5 & 66.7 & \\
\hline \multicolumn{7}{|c|}{ 4.1.4 Ketika berbaris mati (sukun) } & \\
\hline Bil. Responden & 1 & 0 & 1 & 0 & 0 & 19 & \\
\hline Peratusan $(\%)$ & 4.8 & 0 & 4.8 & 0 & 0 & 90.5 & \\
\hline
\end{tabular}

Berdasarkan Jadual 5, 6,7 dan 8 dapatan kajian menunjukkan bahawa seramai 52.4 peratus responden membunyikan huruf [ص ] menjadi huruf [ س], 57.1 peratus responden menyebut huruf [ ض ] sebagai huruf [ 2 ], 52.4 peratus responden membunyikan huruf $[ت]$ ketika menyebut huruf $[\mathrm{b}]$ 
dan 76.2 peratus responden membunyikan huruf [ $b$ ] menjadi huruf [ j]. Perubahan bunyi huruf yang berlaku ini sangat berkait rapat dengan sistem bunyi Kadazandusun yang menjadi identiti dalam diri responden kajian.

Gambaran yang lebih jelas berkenaan gejala gangguan bahasa yang berlaku boleh dilihat melalui perbandingan ringkas antara sistem bunyi kedua-dua bahasa.

Secara umum, huruf Arab [ w] dan konsonan Kadazandusun [ s ] ialah bunyi frikatif alveolar tidak bersuara yang terhasil apabila hujung lidah dirapatkan pada gusi untuk membuat sempitan pada aliran udara. Pita suara berada dalam keadaan terbuka, manakala lelangit lembut dan anak tekak dirapatkan pada dinding tekak untuk menghalang udara keluar daripada rongga hidung. Udara dari paru-paru keluar secara menggeser melalui sempitan pada gusi tanpa menggetarkan pita suara bagi menghasilkan bunyi geseran gusi tidak bersuara. Huruf [ ص ] pula ialah bunyi frikatif alveolar divelarkan tidak bersuara. Pembunyian huruf [ص] sama dengan konsonan [ s ] dan huruf [ w], kecuali ketika penyebutan huruf ini pangkal lidah terangkat ke lelangit lembut dan daun lidah terangkat sedikit ke lelangit keras. Keunikan posisi lidah ketika menyebut huruf [ ص ] tersebut dikenali sebagai ‘ițāq (Al-Juraysī, 1999:76; Huthaily, 2003; Mohd. Azidan, 2004). Selain itu, huruf [ ص ] berkongsi sifat șafir (berdesir) bersama konsonan [s] dan huruf [w].

Huruf [ 2 ] dan konsonan Kadazandusun [ d ] pula ialah bunyi plosif alveolar bersuara. Ia terhasil apabila hujung lidah dirapatkan pada gusi untuk membuat sekatan penuh pada aliran udara. Pita suara berada dalam keadaan tertutup, manakala lelangit lembut dan anak tekak dirapatkan pada dinding tekak untuk menghalang udara keluar melalui rongga hidung. Udara dari paru-paru keluar ke rongga mulut dengan menggetarkan pita suara sebelum tersekat sepenuhnya pada gusi. Seterusnya, udara dilepaskan dengan sertamerta menghasilkan letupan gusi bersuara. Huruf Arab [ ض ] pula ialah bunyi plosif alveolar divelarkan bersuara yang mana pembunyiannya sama dengan konsonan [ d] dan huruf [ $\mathrm{J}$ ], kecuali ia dibunyikan secara 'it $b \bar{a} q$ iaitu ketika penyebutan huruf ini pangkal lidah terangkat ke lelangit lembut dan daun lidah terangkat sedikit ke lelangit keras (Basyīr, 1991; Huthaily, 
2003; Mohd. Azidan, 2004). Selain itu, huruf [ ض ] mempunyai sifat istițālat yang tidak dikongsi bersama konsonan [d] dan huruf [ 2 ]. Sifat istițālat merujuk kepada perihal memanjangkan bunyi huruf ض berbaris mati ketika membunyikannya di tepi lidah daripada bahagian belakang dan dibawa ke hadapan, sementara tepi lidah menempel pada gusi gigi geraham bawah sama ada kiri atau kanan (Al-Juraysī, 1999:85).

Seterusnya, huruf [ $ت$ ] dan konsonan Kadazandusun [ t ] ialah bunyi plosif alveolar tidak bersuara. Ia terhasil apabila hujung lidah dirapatkan pada gusi untuk membuat sekatan penuh pada aliran udara. Pita suara direnggangkan, manakala lelangit lembut dan anak tekak dinaikkan dan dirapatkan pada dinding tekak untuk menghalang udara keluar melalui rongga hidung. Udara dari paru-paru keluar ke rongga mulut dengan menggetarkan pita suara sebelum tersekat sepenuhnya pada gusi. Seterusnya, udara dilepaskan dengan serta-merta menghasilkan letupan gusi tidak bersuara. Huruf [ b ] pula ialah bunyi plosif alveolar divelarkan tidak bersuara yang pembunyiannya sama dengan konsonan $[\mathrm{t}]$ dan huruf [ت], kecuali ia dibunyikan secara 'ițbāq iaitu ketika penyebutan huruf ini pangkal lidah terangkat ke lelangit lembut dan daun lidah terangkat sedikit ke lelangit keras (Basyīr, 1991; Huthaily, 2003; Mohd. Azidan, 2004). Di samping itu, huruf [ $\mathrm{b}$ ] mempunyai sifat qalqalat (perihal lantunan ketika menyebut huruf $b$ berbaris mati atau ketika berhenti) yang tidak dikongsi bersama konsonan [ $\mathrm{t}]$ dan huruf $[\vec{\Xi}]$.

Huruf Arab [ $[$ ] ialah bunyi frikatif interdental divelarkan bersuara yang terhasil apabila hujung lidah dirapatkan pada gigi atas untuk membuat sempitan pada aliran udara sambil pangkal lidah terangkat ke lelangit lembut. Pita suara berada dalam keadaan tertutup, manakala lelangit lembut dan anak tekak dinaikkan dan dirapatkan pada dinding tekak untuk menghalang udara keluar melalui rongga hidung. Udara dari paru-paru keluar secara menggeser melalui sempitan pada gigi dengan menggetarkan pita suara bagi menghasilkan bunyi geseran gigi bersuara (Basyīr, 1991; Huthaily, 2003; Mohd. Azidan, 2004). Huruf [ ל ] tidak mempunyai sifat tunggal dan hanya memiliki sifat unik yang turut dikongsi bersama tiga huruf sebelum ini iaitu sifat tebal 'isti' $l \bar{a}$ ' dan 'ițbāq. 
Huruf [j] dan konsonan bahasa Melayu [ z ] pula ialah bunyi frikatif alveolar bersuara yang terhasil apabila hujung lidah dirapatkan pada gusi untuk membuat sempitan pada aliran udara. Pita suara berada dalam keadaan tertutup, manakala lelangit lembut dan anak tekak dinaikkan dan dirapatkan pada dinding tekak untuk menghalang udara keluar melalui rongga hidung. Udara dari paru-paru keluar secara menggeser melalui sempitan pada gusi dengan menggetarkan pita suara bagi menghasilkan bunyi geseran bersuara (Basyīr, 1991; Huthaily, 2003; Mohd. Azidan, 2004).

Berdasarkan perbandingan ringkas antara sistem bunyi bahasa Arab dan bahasa Kadazandusun di atas, pemindahan bahasa yang berlaku daripada bahasa Kadazandusun kepada bahasa Arab terbahagi kepada dua, iaitu pemindahan positif dan negatif. Pemindahan positif melibatkan sebutan bunyi huruf [ w], [ ] ] [ ] ] dan [ j], manakala pemindahan negatif

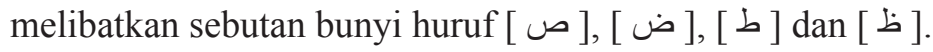

Dari aspek pemindahan positif, Kadazandusun mempunyai bunyibunyi yang hampir sama dengan bunyi yang terdapat dalam sistem bunyi bahasa Arab sama ada dari segi daerah sebutan ataupun cara sebutan. Bunyi konsonan [ s ] seiras dengan huruf [ $\mathrm{w}]$, bunyi konsonan [ d ] serupa dengan huruf [ $[\mathrm{J}$ ] dan bunyi konsonan [ t ] sama dengan huruf [ $[ت$ ]. Antara ciri sepunya yang dikongsi oleh kedua-dua bahasa tersebut ialah bunyi huruf tersebut dilafazkan secara nipis dan tidak berat. Bagi konsonan [ z ] yang menyerupai bunyi huruf [ $j$ ] pula, konsonan tersebut tidak berasal daripada bunyi Kadazandusun dialek Bunduliwan tetapi berasal daripada bahasa Melayu. Penggunaan bahasa Melayu secara meluas dalam kalangan penutur jati Kadazandusun pada hari ini telah menyebabkan mereka mampu membunyikan konsonan tersebut dengan sangat baik (Noor Aina \& Mhd. Amin, 2004). Konsonan [ $\mathrm{z}$ ] dan huruf [ j ] juga memiliki bunyi yang nipis seperti konsonan Kadazandusun dan huruf Arab yang dinyatakan sebelum ini.

Berbeza dengan ciri umum yang dimiliki oleh huruf [ ص ], [ ] ], [ b ] dan [ ] ], huruf-huruf ini ialah huruf Arab yang disebut secara tebal (tafkhìm). Ciri tafkhìm ini terhasil daripada sifat 'isti' lā' (perihal pangkal lidah terangkat ke lelangit lembut) dan 'iṭbāq (perihal daun lidah terangkat 
sedikit ke lelangit keras) yang berlaku secara serentak ketika membunyikan kesemua empat huruf berkenaan dalam semua keadaan sama ada berbaris atas, depan, bawah atau mati. Tambahan itu, setiap huruf tersebut mempunyai sifat unik yang hanya wujud dalam satu huruf dan tidak pada yang lain. Kewujudan ciri-ciri asing ini menyebabkan timbulnya gangguan bahasa ketika responden menyebut huruf [ ص], [ [ ], [ ] dan [ל] kesan daripada pemindahan negatif yang terjadi.

Kesimpulannya, sistem bunyi fonem Arab mempunyai sifat sepunya dan sifat tunggal huruf yang tidak dimiliki oleh bahasa Kadazandusun. Kehadiran sifat sepunya, seperti isti'là' dan 'iṭbāq, dan sifat tunggal huruf, seperti sifat 'istițālat dan qalqalat pada bunyi huruf [ ص], [ض], [ [ ] dan [ ظ] telah mengundang gangguan bahasa Kadazandusun terhadap penyebutan bunyi huruf-huruf tersebut.

Hasil kajian juga menunjukkan bahawa jenis baris huruf seperti baris atas (fathaț), depan (dammaț), bawah (kasrat ) dan mati (sukun), memberi pengaruh yang sangat dominan dan konsisten dalam gangguan bahasa. Dapatan skor dalam Jadual 5, 6,7 dan 8 memberikan indikator jelas bahawa penutur jati Kadazandusun dapat menyebut huruf [ ص ], [ ], [ b ] dan [ $[\mathrm{b}$ ] berbaris atas dengan mudah, namun menghadapi kesukaran untuk menyebut huruf-huruf tersebut ketika berbaris depan, bawah dan mati sehingga membawa kepada gejala perubahan bunyi huruf menjadi huruf yang lain.

Penutur Kadazandusun dapat menyebut huruf [ ص], [ ض ], [ [ ] dan [ $[$ ] berbaris atas secara tebal dengan mudah kerana kewujudan peranan signifikan vokal [ o ] dalam sistem bunyi bahasa Kadazandusun. Gandingan bunyi antara konsonan Kadazandusun [ s, d, t ] serta konsonan Melayu [ z ] dan vokal [ o ] tersebut menghasilkan bunyi tebal yang sangat mirip dengan bunyi huruf [ ص ], [ ], [ ] ] dan [ b ] berbaris atas. Maka tidak hairanlah, peratusan responden menunjukkan prestasi skor ketepatan sebutan bagi setiap huruf yang sangat tinggi iaitu 95.3 peratus, 95.3 peratus, 91.2 peratus dan 76.2 peratus.

Pada masa yang sama, ketiadaan sifat bunyi tebal bagi satu suku kata 
yang terdiri daripada konsonan $[\mathrm{s}, \mathrm{d}, \mathrm{t}, \mathrm{z}]$ dan vokal $[\mathrm{u}, \mathrm{i}]$ dalam sistem bunyi bahasa Kadazandusun dan bahasa Melayu mencetuskan kesukaran dalam penyebutan huruf [ ص ], [ ], [ [ ] dan [ b ] berbaris depan dan bawah (Rita \& Emilda, 2010; Veronica, 2017). Sebagai contoh, ciri sebutan bunyi Kadazandusun ini boleh dilihat pada perkataan /sudai/ - "sisir" dan /sigup/ - "rokok", /duwo/ - "dua" dan /diti/ - "ini”, /tukad/ - "tangga" dan / tirikohon/ - "kerusi". Kesannya, responden melafazkan bunyi huruf [ ص ] menjadi huruf [ w], huruf [ ض ] menjadi huruf [ 2 ], huruf [ $b$ ] menjadi huruf

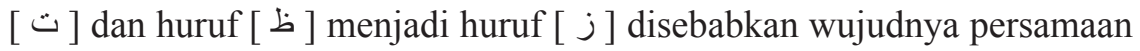
bunyi huruf Arab tersebut dengan bunyi bahasa pertama. Hal ini terbukti seperti yang direkodkan dalam Jadual 5, 6, 7 dan 8 .

Jadual 9 Skor perubahan bunyi huruf $[\varepsilon]$ menjadi huruf [ $\left[{ }^{\prime}\right]$ 5. Huruf $[\varepsilon]$ disebut sebagai huruf [ $\left[{ }^{l}\right]$.

\begin{tabular}{|c|c|c|c|c|c|c|c|}
\hline Tahap Persamaan & $\begin{array}{c}\text { Langsung Tiada } \\
\text { Persamaan }\end{array}$ & $\begin{array}{l}\text { Sangat } \\
\text { Rendah }\end{array}$ & Rendah & Sederhana & Tinggi & $\begin{array}{l}\text { Sangat } \\
\text { Tinggi }\end{array}$ & Tafsiran \\
\hline Bil. Responden & 1 & 3 & 3 & 4 & 3 & $\begin{array}{c}\text { Tinggi } \\
7\end{array}$ & \multirow{2}{*}{$\begin{array}{c}\left.\text { Huruf [ }{ }^{i}\right] \\
\text { mudah disebut }\end{array}$} \\
\hline Peratusan (\%) & 4.8 & 14.3 & 14.3 & 19 & 14.3 & 33.3 & \\
\hline \multicolumn{7}{|c|}{ 5.1.1 Ketika berbaris atas (fathat) } & \\
\hline Bil. Responden & 1 & 7 & 2 & 5 & 1 & 5 & \\
\hline Peratusan $(\%)$ & 4.8 & 33.3 & 9.5 & 23.8 & 4.8 & 23.8 & \\
\hline 5.1.2 Ketika berbari & depan (dammat) & & & & & & \\
\hline Bil. Responden & 1 & 5 & 0 & 5 & 1 & 9 & \\
\hline Peratusan (\%) & 4.8 & 23.8 & 0 & 23.8 & 4.8 & 42.9 & \\
\hline 5.1.3 Ketika berbari & bawah (kasrat) & & & & & & \\
\hline Bil. Responden & 1 & 5 & 3 & 3 & 2 & 7 & \\
\hline Peratusan $(\%)$ & 4.8 & 23.8 & 14.3 & 14.3 & 9.5 & 33.3 & \\
\hline 5.1.4 Ketika berbari & mati (sukun) & & & & & & \\
\hline Bil. Responden & 1 & 5 & 2 & 3 & 3 & 7 & \\
\hline Peratusan $(\%)$ & 4.8 & 23.8 & 9.5 & 14.3 & 14.3 & 33.3 & \\
\hline
\end{tabular}


Jadual 10 Skor perubahan bunyi huruf $[\tau]$ menjadi huruf [ $\bullet$ ] 6. Huruf $[\tau]$ disebut sebagai huruf $[\circ]$.

\begin{tabular}{|c|c|c|c|c|c|c|c|}
\hline Tahap Persamaan & $\begin{array}{l}\text { Langsung Tiada } \\
\text { Persamaan }\end{array}$ & $\begin{array}{l}\text { Sangat } \\
\text { Rendah }\end{array}$ & Rendah & Sederhana & Tinggi & $\begin{array}{l}\text { Sangat } \\
\text { Tinggi }\end{array}$ & Tafsiran \\
\hline Bil. Responden & 1 & 2 & 1 & 1 & 1 & 15 & \multirow{2}{*}{$\begin{array}{c}\text { Huruf }\left[0^{\circ}\right] \\
\text { mudah disebut }\end{array}$} \\
\hline Peratusan $(\%)$ & 4.8 & 9.5 & 4.8 & 4.8 & 4.8 & 71.4 & \\
\hline \multicolumn{7}{|c|}{ 6.1.1 Ketika berbaris atas (fathat) } & \\
\hline Bil. Responden & 2 & 1 & 1 & 0 & 3 & 14 & \\
\hline Peratusan $(\%)$ & 9.5 & 4.8 & 4.8 & 0 & 14.3 & 66.7 & \\
\hline \multicolumn{7}{|c|}{ 6.1.2 Ketika berbaris depan (dammat) } & \\
\hline Bil. Responden & 3 & 1 & 1 & 0 & 1 & 15 & \\
\hline Peratusan $(\%)$ & 14.3 & 4.8 & 4.8 & 0 & 4.8 & 71.4 & \\
\hline \multicolumn{7}{|c|}{ 6.1.3 Ketika berbaris bawah (kasrat) } & \\
\hline Bil. Responden & 3 & 1 & 0 & 1 & 0 & 16 & \\
\hline Peratusan $(\%)$ & 14.3 & 4.8 & 0 & 4.8 & 0 & 76.2 & \\
\hline \multicolumn{7}{|c|}{ 6.1.4 Ketika berbaris mati (sukun) } & \\
\hline Bil. Responden & 2 & 1 & 0 & 3 & 0 & 15 & \\
\hline Peratusan (\%) & 9.5 & 4.8 & 0 & 14.3 & 0 & 71.4 & \\
\hline
\end{tabular}

Berdasarkan Jadual 9 dan 10 dapatan kajian menunjukkan majoriti 47.6 peratus responden membunyikan huruf [ $\varepsilon$ ] menjadi huruf [ $[$ ' ] dan 76.2 peratus responden menyebut huruf $[ح]$ sebagai huruf $[\bullet]$. Perubahan bunyi huruf yang berlaku ini sangat berkait rapat dengan kemiripan sistem bunyi antara bahasa Kadazandusun dan bahasa Arab.

Bagi mendapatkan gambaran yang lebih jelas berkenaan gejala gangguan bahasa yang berlaku ketika responden menyebut huruf [ $\varepsilon]$ dan [ $\ulcorner$ ], maka perbandingan ringkas antara sistem bunyi bahasa Kadazandusun dan bahasa Arab perlu dibuat.

Fonem [ ? ] dan huruf [ I ] ialah bunyi hentian glotis yang berlaku apabila pita suara dirapatkan dengan serapat yang mungkin, manakala lelangit lembut dan anak tekak dinaikkan dan dirapatkan pada dinding tekak untuk menghalang udara keluar melalui rongga hidung. Udara dari paruparu keluar dan tersekat serta terhenti pada bahagian glotis tanpa dilepaskan bagi menghasilkan bunyi hentian glotis. 
Konsonan [ $\mathrm{h}$ ] dan huruf [ 0 ] pula ialah bunyi frikatif glottis bersuara yang terhasil apabila pita suara dibuka atau direnggangkan untuk membuat sempitan pada glotis, manakala lelangit lembut dan anak tekak dinaikkan dan dirapatkan pada dinding tekak untuk menghalang udara keluar melalui rongga hidung. Udara dari paru-paru keluar secara menggeser melalui sempitan glotis. Pita suara bergetar bagi menghasilkan bunyi geseran glotis bersuara (Basyīr, 1991; Huthaily, 2003; Mohd. Azidan, 2004).

Huruf [ $\varepsilon$ ] pula ialah bunyi frikatif kerongkong bersuara, manakala [ $\tau$ ] ialah bunyi frikatif kerongkong tidak bersuara. Sekalipun kedua-dua huruf ini terhasil apabila bahagian tengah kerongkong atau halkum dirapatkan untuk membuat sempitan pada aliran udara, terdapat perbezaan dari aspek penghasilan bunyi bersuara dan tidak bersuara.

Ketika membunyikan huruf [ $[\varepsilon]$ pita suara berada dalam keadaan terbuka, lelangit lembut dan anak tekak dirapatkan pada dinding tekak untuk menghalang udara keluar melalui rongga hidung. Udara dari paru-paru keluar secara menggeser melalui sempitan pada tengah kerongkong dengan menggetarkan pita suara bagi menghasilkan bunyi geseran kerongkong bersuara. Berbeza dengan huruf [ $ح$ ], ketika membunyikannya pita suara berada dalam keadaan tertutup, manakala lelangit lembut dan anak tekak dirapatkan pada dinding tekak untuk menghalang udara keluar melalui rongga hidung. Udara dari paru-paru keluar secara menggeser melalui sempitan pada tengah kerongkong tanpa menggetarkan pita suara bagi menghasilkan bunyi geseran kerongkong tidak bersuara (Basyīr, 1991; Huthaily, 2003; Mohd. Azidan, 2004).

Berdasarkan perbandingan ringkas antara sistem bunyi bahasa Arab dan bahasa Kadazandusun di atas, pemindahan bahasa yang melibatkan sebutan bunyi huruf [ $[$ ] dan [ [ ] adalah termasuk pemindahan positif. Sebutan bunyi huruf $[\varepsilon]$ dan $[\tau]$ berupa pemindahan negatif.

Dari sudut pemindahan positif, bunyi fonem [ ? ] seiras dengan huruf [ $\left.{ }^{i}\right]$ dan bunyi konsonan [ $\mathrm{h}$ ] sama dengan huruf [ $\bullet$ ]. Namun begitu, fonem [ ? ] tidak termasuk sebagai salah satu konsonan Kadazandusun dialek Bunduliwan dan lebih dikenali sebagai sigot ['] yang menjalankan 
beberapa fungsi tatabahasa antaranya pembeza makna perkataan Contohnya, boli' - "babi jantan" dan boli -"membeli" (Veronica, 2017).

Apa yang lebih menarik, bunyi [ ? ] dan [ h ] turut terdapat dalam sistem bunyi bahasa Melayu. Hal ini sekali gus meneguhkan lagi kecekapan penutur Kadazandusun dalam membunyikan huruf [ $[$ ] dan [ [ ] kerana bahasa Melayu turut sama digunakan secara meluas dalam kalangan mereka (Noor Aina \& Mohd. Amin, 2004). Namun, menurut Noor Aina (1996:166) terdapat perbezaan dalam aspek aplikasi bunyi hentian glotis dalam sistem penuturan bahasa Melayu dialek Sabah. Sebagai contoh bunyi hentian glotis /2/ digunakan sebagai pengganti huruf [ $\mathrm{k}$ ] sebagai lambang pada suku kata tertutup (Misalnya, /kaka?/ dan /roko?/) dan digunakan pada akhir suku kata terbuka (Misalnya, dua $=/$ dua?/, kita $=/$ kita? $/$ dan kereta $=/$ kurita? $/$ ).

Dari sudut pemindahan negatif pula, sistem bunyi huruf $[\varepsilon]$ dan $[\tau]$ didapati terlalu asing buat sistem bunyi Kadazandusun. Hal ini demikian kerana bahasa tersebut hanya mempunyai bunyi yang terhasil pada bahagian pangkal kerongkong atau pita suara, namun tidak pada bahagian tengah kerongkong (Rita \& Emilda, 2010; Veronica, 2017). Pertembungan sistem bunyi ini mencetuskan pemindahan negatif yang mencetus gangguan bahasa secara jelas. Akibat daripada gangguan bahasa tersebut, penutur jati Kadazandusun cenderung menyebut [ ? ] ketika membunyikan huruf [ $\varepsilon$ ] dan menyebut [ h ] ketika membunyikan huruf $[\tau]$ kerana sifat bunyinya yang lebih dekat.

\section{KESIMPULAN}

Fenomena gangguan bahasa Kadazandusun sebagai bahasa pertama terhadap sebutan bunyi bahasa Arab sebagai bahasa kedua mencetuskan pemindahan bahasa yang berbentuk positif dan negatif. Pemindahan positif melibatkan huruf-huruf Arab yang mudah disebut oleh penutur jati Kadazandusun, manakala pemindahan negatif pula melibatkan huruf-huruf yang sukar untuk disebut oleh mereka. Tidak dinafikan bahawa gangguan bahasa yang berbentuk pemindahan negatif telah mengundang kesalahan besar dalam sebutan bunyi Arab sehingga mengakibatkan perubahan makna asal perkataan. Dalam konteks amalan ritual keagamaan seperti sembahyang, 
perubahan makna bacaan al-Quran boleh menyebabkan sembahyang yang didirikan tidak sah, bahkan mengundang perbuatan dosa. Namun begitu, pemindahan negatif yang tercetus tidak seharusnya dibayangi oleh persepsi buruk kerana gangguan bahasa tersebut hakikatnya produk daripada sistem bahasa ibunda itu sendiri. Maka, pendekatan yang lebih progresif, kreatif dan inovatif dalam mengajar sebutan hurufArab kepada anak jati Kadazandusun perlu difikirkan, antaranya pembelajaran sebutan huruf Arab menggunakan konsep ansur maju yang mana pembelajaran dimulakan dengan menguasai sebutan huruf-huruf Arab yang mudah dan diakhiri dengan huruf-huruf yang sukar. Oleh hal yang demikian, dengan terbentuknya pengetahuan mendalam berkenaan gangguan bahasa yang dihadapi oleh penutur jati Kadazandusun ketika menyebut huruf Arab, maka ia boleh dijadikan garis panduan khususnya bagi meningkatkan tahap literasi membaca al-Quran dalam kalangan anak jati Kadazandusun yang beragama islam. Garis panduan ini dijangkakan turut memberikan manfaat besar kepada penggubal-penggubal Kurikulum Bahasa Arab dan penulis-penulis buku pembelajaran Bahasa Arab dalam merangka latihan menyebut konsonan Arab.

\section{PENGHARGAAN}

Kajian ini dibiayai oleh geran penyelidikan Universiti Malaysia Sabah (UMS) yang berkod SLB0180-2019.

\section{RUJUKAN}

Abdullah Hassan. (1980). Linguistik Am Untuk Guru Bahasa Melayu. Kuala Lumpur: Fajar Bakti.

Adnan, H., \& Hamdan, M. (2013). Malaysia's 13th general election in Sabah: Factors determining the winners. Jebat: Malaysian Journal of History, Politics \& Strategy, 40(2), 93-112.

Ahmad Sayuti Anshari Nasution. (2014). Memanfaatkan kajian fonetik untuk pengembangan pembelajaran ilmu Tajwid. Arabiyat, Jurnal Pendidikan Bahasa Arab dan Kebahasaan, 1, (2).

Al-Juraysī, Muḥammad Makkī Nașr. (1999). Nihāyat al-Qaul al-Mufíd fi 'ilmi al-Qurān al-Majìd. Kaherah: Maktabat as-Ṣafā 
Ashour, H. M. (2017). Major differences between Arabic and English pronunciation systems: A contrastive analysis study. AL-Lisan International Journal for Linguistic \& Literary Studies, 1(1).

Basyīr, Kamāl Muhammad. (1991). al-Așwāt al- 'Arabiyyat. Cairo: Maktabah al-Syabāb Chua, Y. P. (2006). Kaedah Penyelidikan. Kuala Lumpur: McGraw-Hill.

Ehala, M. (2010). Ethnolinguistic vitality and intergroup processes. Multilingua, 29, 203- 221.

Hanna, Sāmi Ayād. (1991). Mabādi' 'Ilm al-Lisāniyāt al-Hadītsah. Alexandria: Dār al-Ma'rifah al- Jāmi 'iyah

Harun Baharudin, Maimun Aqsha Lubis \& Mohd. Nik Rahimi Nik Yusoff. (2018). Tajweed learning through the support of Arabic phonetic. Jurnal Hadhari, 10 (2), 259-274.

Huthaily, Khaled. (2003). Contrastive phonological analysis of Arabic and English. Graduate Student Theses, Dissertations \& Professional Papers, 8110. https://scholarworks.umt.edu/etd/8110

Issraq Ramli. (2017). Aplikasi teori Mahjub dalam memperbaiki penyebutan bunyi bahasa Arab dalam kalangan pelajar Sabah. Tesis PhD (Tidak diterbitkan). Fakulti Bahasa dan Linguistik. Kuala Lumpur: Universiti Malaya.

Mahjub, 'Abdul Fatah. (1993). Ta'lim wa Ta'allum al-Aswat al-'Arabiyyat alSa 'bat Li Ghair al-Natiqin Biha, Lil Mu'allim Wa al-Muta'allim. Al-Tab'at al-Thaniat. Ma'ahad al-Lughat al-'Arabiyyat. Universiti Umm al-Qura.

Majid, Z. B. A. (2017). Contrastive analysis and the teaching of the French sound system. Journal of Modern Languages, 2, 102-119.

Mohd Azidan bin Abdul Jabar. (2004). Gangguan bunyi Melayu dalam sebutan Arab: Satu analisis ringkas. Pertanika J. Soc. Sci \& Hum, 12 (2).

Mohd. Taqwudin Mohd. Yazid \& Veronica Petrus Atin. (2019). Similarities and differences: A preliminary comparative study of Arabic and Kadazandusun phonology. International Journal of Academic Research in Business and Social Sciences, 9(2), 804-817.

Moradi, H., \& Chen, J. (2018). A contrastive analysis of Persian and english vowels and consonants. Lege Artis, 3(2), 105-131.

Muhiddin Yusin. (1990). Islam di Sabah. Kuala Lumpur: Dewan Bahasa dan Pustaka.

Noor Aina Dani. (1996). Pemindahan bahasa dalam proses pembelajaran bahasa Melayu pelajar-pelajar Dusun. Tesis Doktor Falsafah (Tidak diterbitkan). Serdang: Universiti Putra Malaysia.

Noor Aina Dani \& Mohd. Amin Arshad. (2004). Teori dan realiti perubahan bahasa: daripada bahasa ibunda kepada bahasa Melayu. Jurnal Bahasa, 4, (3), 409-451.

Noor Aina Dani, Norazlina Mohd. Kiram, Mohd. Ariffin Mohd. Arif, Kamarlin Ombi, Roslan Suhailin, Sharil Nizam Sha'ri \& Daisy Paul. (2019). Endangered intergenerational language transmission: Evidence from the indigenous Dusun society of Sabah, Malaysia. Pertanika J. Soc. Sci. \& Hum, 27(1), 1-12. 
Nor Hasmah Jalaludin. (2000). Asas fonetik (Cetakan Ke2). Kuala Lumpur: Dewan Bahasa dan Pustaka.

Rita Lasimbang \& Emilda Evon. (2010). Rujukan Ringkas Aspek Linguistik Bahasa Kadazandusun. Kota Kinabalu: Kandavai Books.

Samarin, W. J. (1993). Linguistik lapangan panduan kerja lapangan Linguistik. Kamaruzaman Mahayiddin \& Zahrah Abd. Ghafar (penterj.). Kuala Lumpur: Dewan Bahasa dan Pustaka.

Suraya Sintang. (2013). Kehidupan beragama masyarakat Kadazandusun (Ed. ke2). Kota Kinabalu: Penerbit Universiti Malaysia Sabah.

Tarigan, H.G. (1988). Pengajaran analisis kesalahan berbahasa. Bandung: Penerbit Angkasa.

Veronica Petrus Atin. (2017). UD00102 Kadazandusun Level 1: Course Modul (Unpublished).

Wurm, S. A., \& Hattori, S. (1981). Language atlas of the Pacific area, part 1 and 2. Canberra, Australia: Australian National University. 